\title{
sciendo
}

CIVIL AND ENVIRONMENTAL ENGINEERING REPORTS

E-ISSN 2450-8594

CEER 2018; 28 (3): 065-078

DOI: $10.2478 /$ ceer-2018-0035

Original Research Article

\section{PROPERTIES OF THE ORGANIC FRACTION DIRECTED TO BIOSTABILIZATION IN MBT INSTALLATIONS DURING THE HEATING SEASON}

\author{
Andrzej JĘDRCZAK ${ }^{1}$ \\ University of Zielona Góra, Zielona Góra, Poland
}

\begin{abstract}
In the professional literature, there is no information about the sieve and morphological composition OFMSW ( $<80 \mathrm{~mm}$ ) subjected to biological processing in MBT installations during the heating season. Knowledge about the quality of this fraction is important because it significantly affects the course of the biostabilization process. The paper presents the morphological composition, sieve composition, humidity, loss on ignition and organic carbon content of $<80 \mathrm{~mm}$ fraction separated from municipal waste delivered to $21 \mathrm{MBT}$ installations in Poland, in winter. The results show that about $1 / 3$ of the OFMSW $(34.0 \pm 10.6 \%)$ mass is a fine fraction $(<20 \mathrm{~mm})$, mainly furnace waste. The organics share was on average $39.3 \pm 10.4 \%$. The fraction "paper and cardboard" was also present in the bulk of OFMSW, an average of $10.5 \pm 4.3 \%$. The shares of other components did not exceed 5\%. The large number of batteries in OFMSM was surprising, despite their widespread selective collection. The high content of fine fraction (ashes) and inert components in OFMSW during the heating season results in low hydration and low losses of waste incineration, which may even determine their inability to be processed biologically.
\end{abstract}

Keywords: Municipal solid waste, MBT plants, OFMSW, Composting systems Organic fraction, Biodegradable waste

\footnotetext{
${ }^{1}$ Corresponding author: University of Zielona Góra, Institute of Environmental Engineering, Szafrana st 15, 65-246 Zielona Góra, Poland, a.jedrczak@iis.uz.zgora.pl
} 


\section{INTRODUCTION}

The handling of biodegradable waste since 1999 is defined in Directive 1999/31/EC. It imposes on EU Member States the implementation of one of the most ambitious and important waste policies - reducing the amount of biodegradable waste discharged to landfills, while encouraging the implementation of alternative strategies, to shift to a more sustainable waste management system consistent with the hierarchy of waste management.

In order to achieve European goals, Member States have adopted different options for dealing with solid municipal waste (MSW), such as incineration of MSW with energy recovery or separation of biodegradable waste from the MSW stream by their selective collection or mechanical separation in industrial installations before further processing environmentally safe biological methods, such as composting and methane fermentation. Among them, the mechanicalbiological waste treatment (MBT) technology, aimed at biological stabilization of the organic fraction of municipal waste (OFMSW) prior to storage, plays a key role in the MSW economy system.

The biological degradation of OFMSW before disposal of waste to the landfill provides many environmental benefits, such as reduction of greenhouse gas emissions $[1,2,3,4]$, reduction of leachate $[1,5,6,7]$ and increase of calorific value of raw material for fuel production waste [8]. In addition, waste treatment costs in MBT installations are competitive in relation to their combustion. This led to the construction of numerous MBT installations both in developing countries, where technical choices are also shaped by economic considerations, as well as in countries with strong opposition to the implementation of thermal waste treatment technologies $[9,10]$.

At the end of 2016, approximately 570 MBT installations with a capacity of 55 million $\mathrm{Mg}$ were used in Europe. It is expected that another 120 objects with a total capacity of about 10 million $\mathrm{Mg} / \mathrm{a}$ will be put into service by 2025 . The market position of MBT technology will continue to be strong in the coming years, although the pace of construction of these installations will clearly decrease [11].

In Poland, at the end of 2016, there were 192 MBP installations with a capacity of around 11 million $\mathrm{Mg}$ of waste per year. The total capacity of installations using methane fermentation to stabilize the OFMSW did not exceed 200,000. $\mathrm{Mg} / \mathrm{a}$, although this method has a number of advantages over composting [12].

The course of stabilization of the OFMSW depends on their properties such as: organic matter content, particle size, moisture content, ratio $\mathrm{C}: \mathrm{N}$ and the content of non-compostable ingredients $[13,14,15]$. Humidity is a critical parameter in the composting process. It affects the rate of oxygen uptake, air porosity, microbiological activity and process temperature [16]. The moisture content of 
the composting batch should be 50-60\% [13, 15]. The limiting value of the share of organic matter in the waste, which allows for biological treatment, is assumed to be loss on ignition $>30 \%$ [17].

The size of the particles has a big influence on maintaining proper waste porosity for proper aeration. In general, the greater the refinement of waste, the higher the composting speed. Too small particle size reduces the air porosity of the charge and thus the availability of oxygen $[13,15]$.

In the professional literature, there is no information about the sieve and morphological composition of OFMSW $(<80 \mathrm{~mm})$ subjected to biological processing in MBT installations. There is no information about the properties of these wastes during the heating season.

The paper presents the morphological composition, sieve composition, humidity, loss of roasting (LOI) and organic carbon content (TOC) of the $<80$ $\mathrm{mm}$ fraction separated from municipal waste delivered to $21 \mathrm{MBT}$ installations in Poland, in winter.

The data presented in this article supplements knowledge about the quality of OFMSW in the winter period and their suitability for biological processing in MBT installations.

\section{MATERIALS AND METHODS}

The waste used in this study was the MSW delivered during the winter period (January-February 2015) to 21 full-scale MBT plants using various waste treatment technologies (Table 1).

General MSW samples were prepared by taking 5 primary samples, with a minimum mass of approximately $100 \mathrm{~kg}$ each, from the installation lines, at regular intervals during a typical working day. The obtained general samples were reduced by quartering to the amount of approx. $100 \mathrm{~kg}$. Three samples of the MSW were collected in each installation.

The sieve composition of the samples and the material composition of the separated sieve fractions were determined on site.

The sieve analysis included separating the waste sample into fractions: $<10 \mathrm{~mm}$, $10-20 \mathrm{~mm}, 20-40 \mathrm{~mm}, 40-80 \mathrm{~mm}, 80-100 \mathrm{~mm} \&>100 \mathrm{~mm}$.

The scope of material analysis included:

- $0-10 \mathrm{~mm}$ and 10-20 $\mathrm{mm}$ fractions: breakdown into biodegradable and nonbiodegradable fractions,

- fractions $20-40 \mathrm{~mm}, 40-80 \mathrm{~mm}, 80-100 \mathrm{~mm}$ and $>100 \mathrm{~mm}$ : breakdown into ingredients: organic, paper, plastics, glass, textiles, metals, hazardous, composite, inert and others. 
Table 1. Installations and waste samples covered by the tests

\begin{tabular}{|c|c|c|c|c|c|}
\hline \multirow{2}{*}{$\begin{array}{l}\text { Installation } \\
\text { Sample No. }\end{array}$} & \multicolumn{2}{|c|}{$\begin{array}{l}\text { Designed processing } \\
\text { capacity } \\
\text { [thous. } \mathrm{Mg} / \text { year] }\end{array}$} & \multicolumn{2}{|l|}{ Intensive phase } & \multirow{2}{*}{$\begin{array}{l}\text { Maturing in } \\
\text { windrows, } \\
\text { days }\end{array}$} \\
\hline & $\begin{array}{l}\text { Mechanical } \\
\text { part }\end{array}$ & $\begin{array}{l}\text { Biological } \\
\text { part }\end{array}$ & Reactor & $\begin{array}{c}\text { Duration } \\
\text { of study, } \\
\text { days }\end{array}$ & \\
\hline MBP1 & 70 & 18 & $\begin{array}{l}\text { Dry fermentation, mesophilic } \\
\text { fraction }<60 \mathrm{~mm} \text {, after } \\
\text { removal of Fe and hard parts }\end{array}$ & 25 & $20 *$ \\
\hline MBP2 & 50 & 30 & $\begin{array}{l}\text { Dry fermentation, thermophilic } \\
\text { fraction }<40 \mathrm{~mm} \text {, after } \\
\text { removal of Fe and hard parts }\end{array}$ & 26 & 21 \\
\hline $\begin{array}{l}\text { MBP3 } \\
\text { MBP4 } \\
\text { MBP5 }\end{array}$ & $\begin{array}{c}210 \\
59 \\
80 \\
\end{array}$ & $\begin{array}{l}95 \\
19 \\
33 \\
\end{array}$ & $\begin{array}{l}\text { Reinforced concrete boxes in } \\
\text { the hall, with forced aeration } \\
\text { and transfer of waste }\end{array}$ & $\begin{array}{l}24 \\
28 \\
25 \\
\end{array}$ & $\begin{array}{l}42 \\
33 \\
41 \\
\end{array}$ \\
\hline $\begin{array}{l}\text { MBP6 } \\
\text { MBP7 } \\
\text { MBP8 }\end{array}$ & $\begin{array}{c}45 \\
70 \\
157 \\
\end{array}$ & $\begin{array}{c}26 \\
16 \\
100\end{array}$ & $\begin{array}{c}\text { Reinforced concrete reactors } \\
\text { with reinforced concrete or } \\
\text { plastic ceiling }\end{array}$ & $\begin{array}{l}29 \\
35 \\
24\end{array}$ & $\begin{array}{l}42 \\
24 \\
33\end{array}$ \\
\hline $\begin{array}{l}\text { MBP9 } \\
\text { MBP10 } \\
\text { MBP11 }\end{array}$ & $\begin{array}{l}80 \\
72 \\
27 \\
\end{array}$ & $\begin{array}{l}21 \\
16 \\
13 \\
\end{array}$ & $\begin{array}{c}\text { Reinforced concrete reactors } \\
\text { with reinforced concrete or } \\
\text { plastic ceiling }\end{array}$ & $\begin{array}{l}23 \\
29 \\
27\end{array}$ & $\begin{array}{l}19 \\
55 \\
41\end{array}$ \\
\hline $\begin{array}{l}\text { MBP12 } \\
\text { MBP13 }\end{array}$ & $\begin{array}{l}60 \\
85\end{array}$ & $\begin{array}{l}30 \\
28\end{array}$ & $\begin{array}{c}\text { Boxes with gates and roofs } \\
\text { covered with GORE® } \\
\text { laminates }\end{array}$ & $\begin{array}{l}30 \\
22\end{array}$ & $\begin{array}{l}47 \\
63\end{array}$ \\
\hline MBP14 & 65 & 20 & Steel reactors (containers) & 18 & 35 \\
\hline MBP15 & 50 & 25 & $\begin{array}{l}\text { No reactor (the whole process } \\
\text { in open prisms) }\end{array}$ & - & 84,134 \\
\hline $\begin{array}{l}\text { MBP16 } \\
\text { MBP17 }\end{array}$ & $\begin{array}{c}150 \\
44\end{array}$ & $\begin{array}{l}75 \\
16\end{array}$ & Foil sleeves & $\begin{array}{l}51 \\
50\end{array}$ & - \\
\hline MBP18 & 60 & 26 & $\begin{array}{l}\text { GORE® laminates coated } \\
\text { prisms }\end{array}$ & 56,70 & - \\
\hline
\end{tabular}

* bio tunnels (digestate + fraction $60-80 \mathrm{~mm}$ ) 
Samples of sorted materials were immediately transferred to a laboratory where they were maintained for a maximum period of 24 hours at $4^{\circ} \mathrm{C}$ to hinder biological activity.

In the laboratory, from the provided samples, after their homogenisation, representative samples were prepared for laboratory analysis, including the indications: moisture, loss of ignition and organic carbon (in duplicate).

Material and physico-chemical analysis of waste was carried out in accordance with the standards and procedures presented in Table 2 .

Table 2. Waste testing methodology

\begin{tabular}{|c|l|l|}
\hline No. & \multicolumn{1}{|c|}{ Indicator } & \multicolumn{1}{|c|}{ Standard or procedure } \\
\hline 1. & $\begin{array}{l}\text { Performing material analysis of the } \\
\text { MSW sample } *\end{array}$ & PN-Z-15006: 1993 \\
\hline 2. & $\begin{array}{l}\text { Determination of the moisture content } \\
\text { of the sample }\end{array}$ & $\begin{array}{l}\text { PN-Z-15008/02: 1993, PN-EN } \\
\text { 14346: 2011 }\end{array}$ \\
\hline 3. & $\begin{array}{l}\text { Determination of sample ignition loss } \\
\text { (LOI) }\end{array}$ & PN-EN 15169: 2011+Ap1:2012 \\
\hline 4 & Determination of organic carbon (TOC) & PN-EN 13137: 2004 \\
\hline
\end{tabular}

* The scope of the material analysis included the following components: organic, paper, plastics, glass, textiles, metals, hazardous, composite, inert and others.

\section{RESULTS AND DISCUSSION}

\subsection{MIXED MUNICIPAL WASTE}

\subsubsection{THE SIEVE COMPOSITION OF WASTE}

The results of screening tests of the MSW are presented in Figure 1. The weight of the tested samples ranged from 95.2 to $104.4 \mathrm{~kg}$ (average $101.9 \mathrm{~kg}$ ).

The sieve composition of waste delivered to 21 MBP systems under investigation was very diverse. The waste was dominated by the fraction $>100$ $\mathrm{mm}$ (from 17.9 to $67.6 \%$, average $38.7 \pm 10.4 \%$ ), and the fine fraction of $<20$ $\mathrm{mm}$ was on average $17.1 \pm 7.6 \%$, including:

- fraction $<10 \mathrm{~m}-9.3 \pm 5.6 \%$ (from 2.6 to $22 \%$ ) and

- fraction $10-20 \mathrm{~mm}-7.9 \pm 2.5 \%$ (from 2.8 to $13.8 \%$ ) (fig. 1 ).

The total share of fine fractions $(<20 \mathrm{~mm})$ in waste greater than $30 \%$ was determined in three installations. The percentages of fraction $<10 \mathrm{~mm}$ in waste from these installations were successively: 22,$0 ; 20,5$ and $16,8 \%$. In the next four installations, the share of this fraction exceeded $10 \%(10.5,11.5,11.6$ and $17.0 \%$ ). The high share of the fraction $<10 \mathrm{~mm}$ in the waste was due to the presence of ash in the waste, which resulted from the testing during the heating season. 


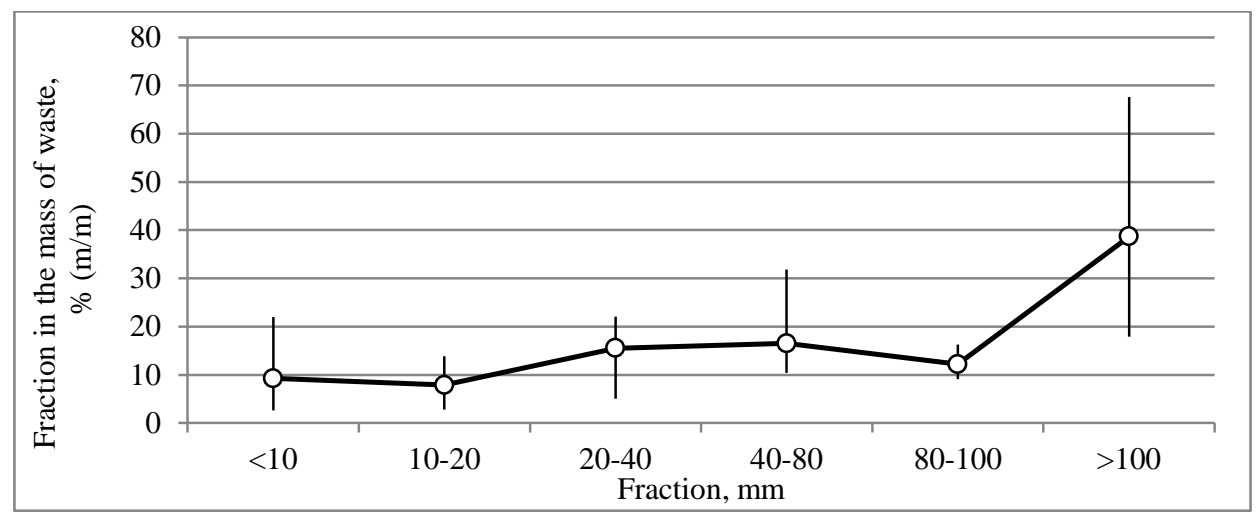

Fig. 1. MSW sieve composition (range of values, mean value)

\subsubsection{THE MORPHOLOGICAL COMPOSITION OF WASTE}

Figure 2 presents the average morphological composition of the MSW investigated, and in Table 3 the statistical assessment of these analysis results, giving:

- range $(\mathrm{R})$ - difference between the maximum and minimum value of the trait - a characteristic of the empirical area of variability of the trait tested;

- arithmetic average $(\bar{X})$;

- standard deviations $\left(\mathrm{S}_{\mathrm{X}}\right)$;

- median (Me);

- coefficient of variation - quotient of absolute measurement of variability of the trait and mean value of this trait $\left(\vartheta_{\bar{X}}=\frac{S_{X}}{\bar{X}} \cdot 100\right)$, given in percent.

The average morphological composition of municipal waste from individual regions was very diverse. Assuming the coefficient of variability as the criterion, this was most evident for hazardous waste, components present in small quantities: the range of values from 0.00 to $0.40 \%$, on average $-0.04 \%$, coefficient of variation $-240 \%$; including batteries: 0.00 to 0.08 , average -0.01 ; coefficient of variation $-172 \%$.

For fractions $<10 \mathrm{~mm}$, textiles, multi-material components and inert components, the coefficient of variation assumed values in the range of 40$100 \%$ (high variability), and for other components it ranged from $20-40 \%$ (average variability). 


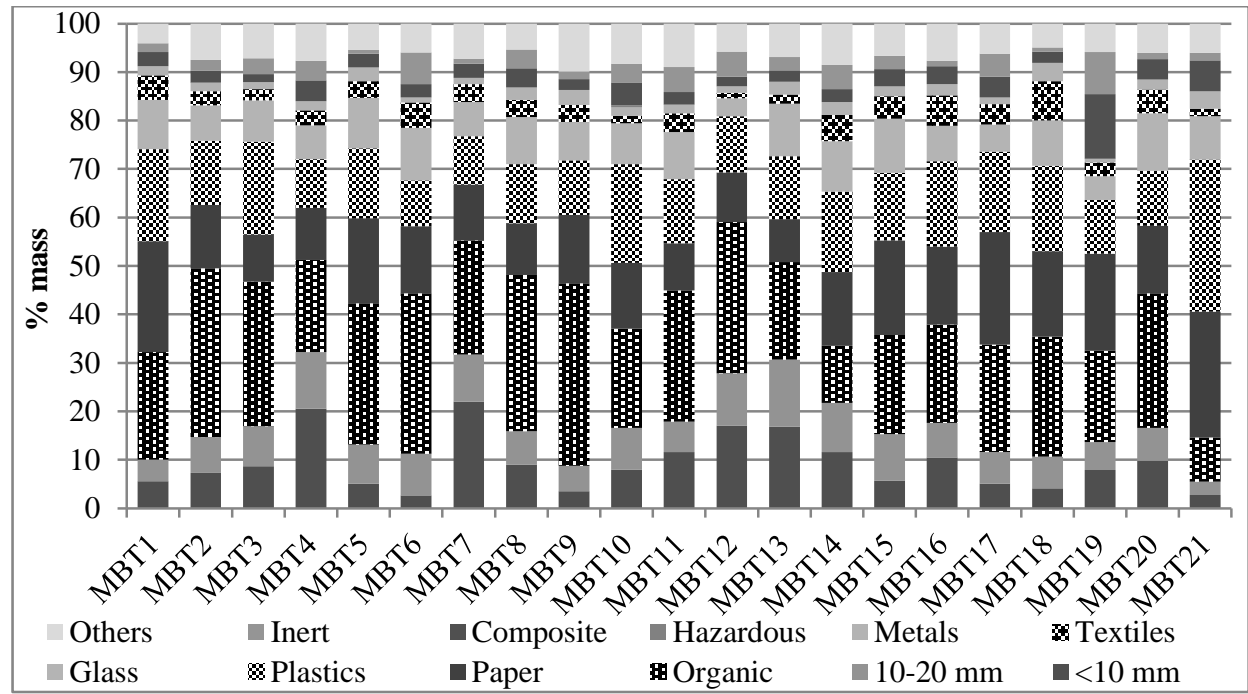

Fig. 2. The average morphological composition of MSW

Table 3. Statistical evaluation of the results of morphological composition analyzes of MSW samples delivered to $21 \mathrm{MBT}$ installations

\begin{tabular}{|l|c|c|c|c|c|c|c|}
\hline Specification & $\begin{array}{c}\text { Minimum } \\
\text { value }\end{array}$ & $\begin{array}{c}\text { Maximum } \\
\text { value }\end{array}$ & Gap & $\begin{array}{c}\text { Average } \\
\text { value }\end{array}$ & $\begin{array}{c}\text { Standard } \\
\text { deviation }\end{array}$ & Median & $\begin{array}{c}\text { Variation } \\
\text { coefficient }\end{array}$ \\
\hline$<10 \mathrm{~mm}$ & 2.6 & 22.0 & 19.4 & $\mathbf{9 . 3}$ & 5.6 & 7.9 & 61 \\
\hline $10-20 \mathrm{~mm}$ & 2.8 & 13.8 & 11.1 & $\mathbf{7 . 9}$ & 2.5 & 7.4 & 32 \\
\hline Organic & 9.1 & 37.6 & 28.5 & $\mathbf{2 4 . 6}$ & 7.3 & 23.5 & 29 \\
\hline Paper & 8.9 & 26.0 & 17.1 & $\mathbf{1 5 . 1}$ & 4.9 & 13.9 & 32 \\
\hline Plastics & 9.5 & 31.4 & 21.9 & $\mathbf{1 4 . 9}$ & 5.0 & 13.2 & 34 \\
\hline Glass & 3.7 & 11.9 & 8.1 & $\mathbf{8 . 6}$ & 2.2 & 8.9 & 25 \\
\hline Textiles & 1.1 & 8.1 & 6.9 & $\mathbf{3 . 8}$ & 1.7 & 3.6 & 45 \\
\hline Metals & 0.7 & 3.8 & 3.1 & $\mathbf{2 . 1}$ & 0.8 & 1.9 & 39 \\
\hline Hazardous & 0.00 & 0.40 & 0.40 & $\mathbf{0 . 0 4}$ & 0.09 & 0.00 & 240 \\
\hline Composite & 1.6 & 13.4 & 11.8 & $\mathbf{3 . 7}$ & 2.5 & 2.9 & 67 \\
\hline Inert & 0.8 & 8.7 & 7.8 & $\mathbf{3 . 2}$ & 2.1 & 2.7 & 65 \\
\hline Others & 4.0 & 9.9 & 5.9 & $\mathbf{6 . 8}$ & 1.4 & 6.7 & 25 \\
\hline
\end{tabular}




\subsubsection{ORGANIC FRACTION OF MUNICIPAL WASTE $(<80 \mathrm{MM})$}

\subsubsection{THE PARTICIPATION OF OFMSW IN THE MASS OF MSW}

The share of OFMSW $(<80 \mathrm{~mm})$ in the municipal waste stream is shown in Figure 3 . The average value of the indicator is $49.1 \pm 10.2 \%$. The discrepancy in the value of this indicator was very high. In two installations, the share of the fraction did not exceed 40\% (MBT21 - 20.9\% and MBT1 - 35.4\%), in five installations it was close to 60\%, and one was even 70\% (MBT12 -68.0\%).

\subsubsection{THE MORPHOLOGICAL COMPOSITION OF OFMSW}

Figure 4 presents the average morphological composition of $<80 \mathrm{~mm}$ fraction separated from MSW samples, expressed as a percentage of the total wet weight, and in Table 4 a statistical evaluation of these analysis results.

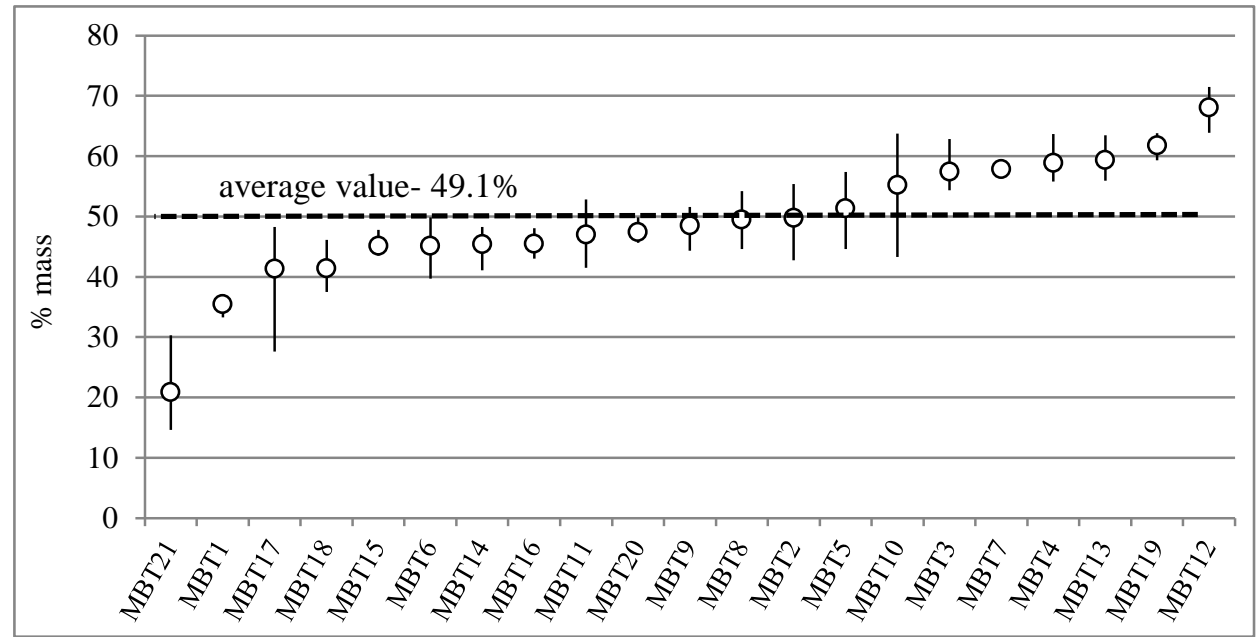

Fig. 3. The participation of OFMSW in the mass of MSW

In OFMSW the largest number of so-called "organics" (food waste, waste from parks and gardens, and other organic waste). The total share of "organics" ranged from 17.5 to $62.6 \%$, on average it was $38.4 \pm 10.1 \%$. Food waste, whose share in the OFMSW was on average $7.9 \pm 11.2 \%$ (from 0.1 to $37.1 \%$ ), accounted for $20.6 \%$ of the weight of "organic". The share of "organics" in OFMSW should be considered low in comparison to other studies [18]. 


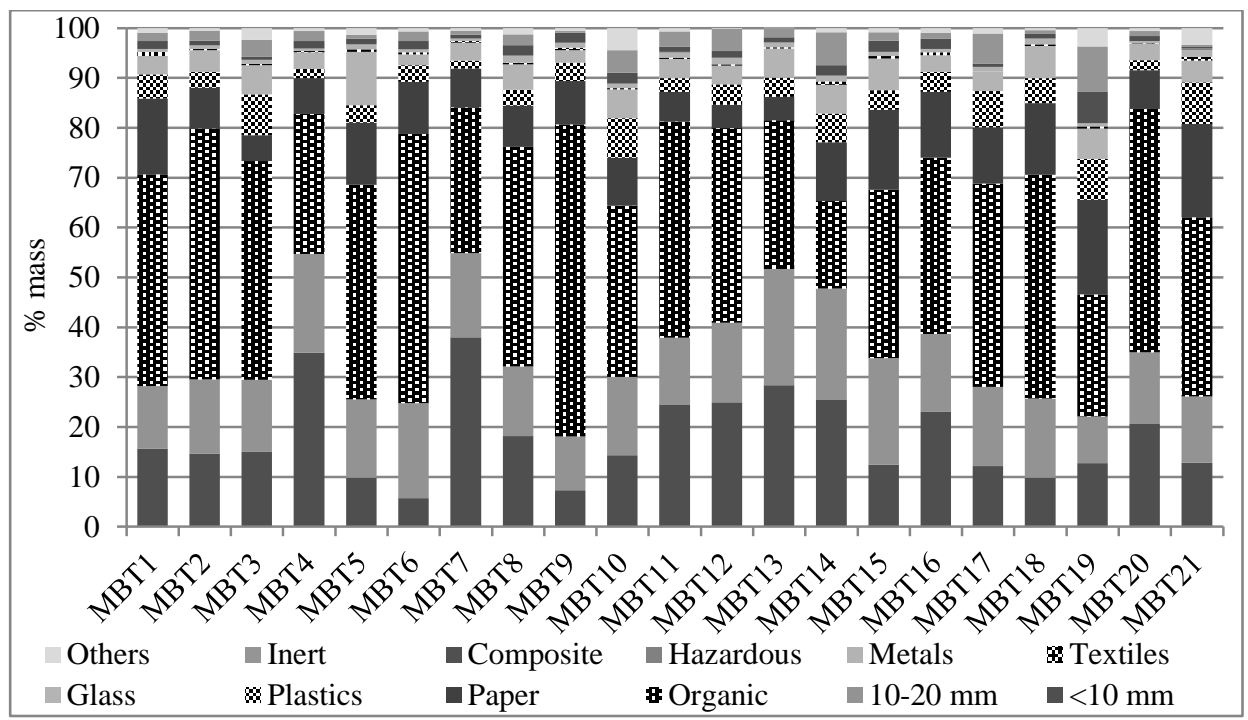

Fig. 4. The average morphological composition of OFMSW $(<80 \mathrm{~mm})$ from the $21 \mathrm{MBP}$ installations covered by the research

Table 4. Statistical evaluation of the results of morphological composition analyzes of OFMS samples

\begin{tabular}{|l|c|c|c|c|c|c|c|}
\hline Specification & $\begin{array}{c}\text { Minimum } \\
\text { value, \% }\end{array}$ & $\begin{array}{c}\text { Maximum } \\
\text { value, \% }\end{array}$ & Gap & $\begin{array}{c}\text { Average } \\
\text { value, \% }\end{array}$ & $\begin{array}{c}\text { Standard } \\
\text { deviation }\end{array}$ & Median & $\begin{array}{c}\text { Coefficient } \\
\text { of variation }\end{array}$ \\
\hline$<10 \mathrm{~mm}$ & 5.7 & 38.0 & 32.3 & $\mathbf{1 8 . 1}$ & 8.7 & 15.0 & 48 \\
\hline $10-20 \mathrm{~mm}$ & 9.4 & 23.3 & 13.9 & $\mathbf{1 5 . 9}$ & 3.6 & 15.7 & 22 \\
\hline Organic & 17.5 & 62.6 & 45.0 & $\mathbf{3 8 . 4}$ & 10.1 & 39.0 & 26 \\
\hline Paper & 4.7 & 18.9 & 14.3 & $\mathbf{1 0 . 5}$ & 4.3 & 9.7 & 41 \\
\hline Plastics & 1.6 & 8.3 & 6.7 & $\mathbf{4 . 7}$ & 2.2 & 4.1 & 46 \\
\hline Glass & 2.6 & 6.4 & 3.8 & $\mathbf{4 . 7}$ & 1.2 & 4.4 & 26 \\
\hline Textiles & 0.0 & 0.8 & 0.8 & $\mathbf{0 . 4}$ & 0.2 & 0.3 & 54 \\
\hline Metals & 0.4 & 1.5 & 1.1 & $\mathbf{0 . 9}$ & 0.3 & 0.9 & 35 \\
\hline Hazardous & 0.00 & 0.43 & 0.43 & $\mathbf{0 . 0 5}$ & 0.10 & 0.00 & 213 \\
\hline Composite & 0.3 & 6.3 & 6.0 & $\mathbf{1 . 6}$ & 1.2 & 1.3 & 78 \\
\hline Inert & 0.3 & 9.1 & 8.7 & $\mathbf{3 . 0}$ & 2.4 & 2.0 & 81 \\
\hline Others & 0.1 & 7.3 & 7.2 & $\mathbf{1 . 8}$ & 1.9 & 1.0 & 102 \\
\hline
\end{tabular}


A fine fraction $(<20 \mathrm{~mm})$ also occurred in bulk waste $(<20 \mathrm{~mm})$, an average of $34.0 \pm 10.6 \%$, resulting in oversizing of OFMSW processing equipment. The largest amounts of this fraction contained OFMSW samples collected in the "MBT7" installation - 54.8\%. The $<10 \mathrm{~mm}$ fraction was essentially a contaminated ash. The fine fraction in large quantities also occurred in the biofraction of the "MBT4" installation (54.7\%), "MBT13" (51.6\%), "MBT14" (47.7\%) and "MBT12" (40.9\%). (Fig. 5).

Waste of paper, plastic and glass were present in OFMSW in large quantities, representing on average $19.9 \pm 6.2 \%$ of the total amount of waste. A high percentage of the "paper" fraction, on average - $10.5 \pm 4.3 \%$ (from 4.7 to $18.9 \%$ ), does not favor the course of the composting process due to the high content of lignin present in the material. Lignin is a polymer that is biodegradable very slowly, which reduces the speed of the whole process [19]. In turn, the presence of plastics $(4.7 \pm 2.2 \%)$ is not an obstacle, because they behave practically indifferently during composting, and even provide greater porosity of waste, which promotes their aeration. The content in OFMSW of glass $(4.7 \pm 1.2 \%)$ is similar, which is the most visible contamination of the final product, although it is not a dangerous component.

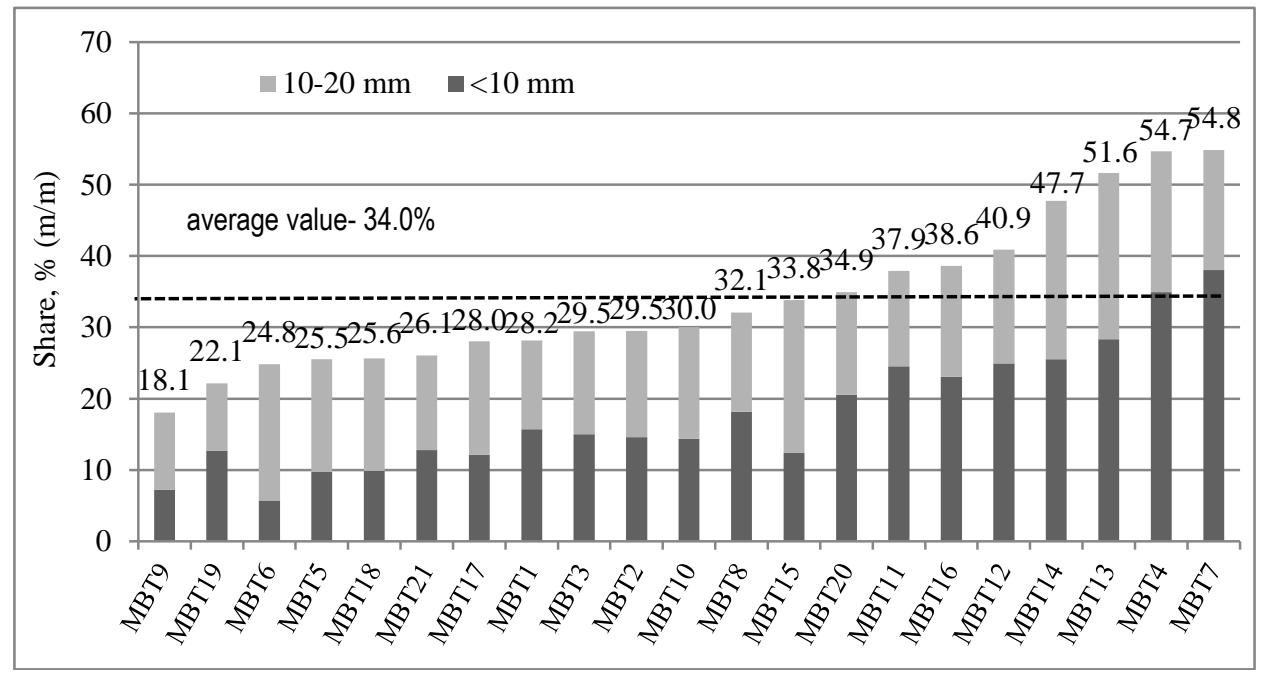

Fig. 5. Share of fine fraction $(<20 \mathrm{~mm})$ in OFMSW from installations covered by research

The metals were present in OFMSW in the amount $(0.9 \pm 0.3 \%)$. The content of hazardous waste was on average $0.05 \%$ of the waste mass (from 0.00 to $0.43 \%$ ). An unexpected result was finding batteries in OFMSW in 4 MBT installations. In one installation, the share of batteries reached $0.36 \%$ of the waste mass. All batteries that were previously in the Ministry of Internal Affairs went through 
the OFMSW samples. Batteries are considered to be highly dangerous due to the high content of heavy metals (zinc, cadmium).

\subsubsection{HUMIDITY AND VALUE OF ROASTING LOSSES AND ORGANIC CARBON CONTENT}

Humidity and the value of roasting losses and organic carbon content in OFMSW are shown in Figure 6.

OFMSW contained an average of $36.9 \pm 10.1 \%$ water (range of values: 25,0 $57,9 \%)$. The volatility index was $27 \%$. Moisture higher than $50 \%$ was exhibited by OFMSW collected in the MBT10 installation (57.9\%) and MBT17 (57.7\%). The average humidity above $45 \%$ was also found in the samples from the MBT13 installation (46.3\%). Very low moisture was found in MBT20 installations $(25.0 \%)$. In five consecutive installations, the humidity was lower by $30 \%$. MBT18 (26,4\%), MBT15 (27,5\%), MBT4 (28,3\%), MBT8 $(29,1 \%) \&$ MBT2 \& $7(29,3 \%)$. Such high OFMSW drying, caused to a large extent by high ash content, is very unfavourable. This can cause slow composting even after rehydrating the waste to an optimal level.

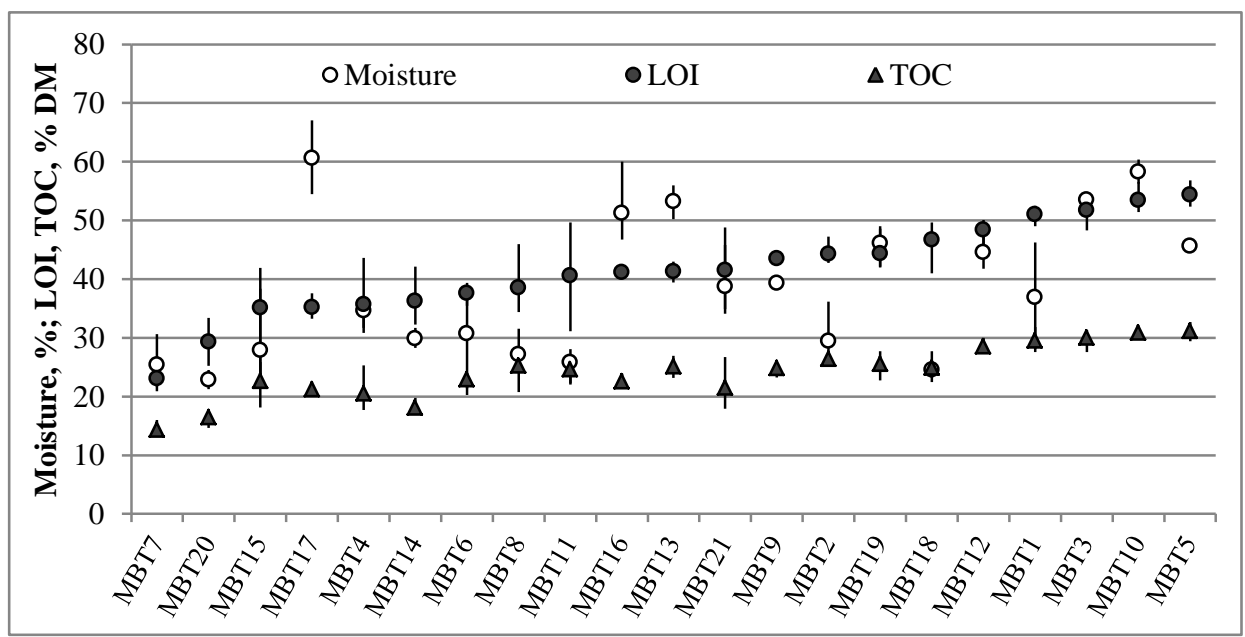

Fig. 6. Average values of humidity and content of organic substances (LOI) and organic carbon (TOC) of OFMSW samples

The average value of the loss of the OFMSW roasting was $38.1 \pm 7.2 \% \mathrm{DM}$ (from 25.5 to $50.7 \% \mathrm{DM}$ ). The volatility index was $19 \%$. In two installations (MPT7 and MBT20), the loss of ignition was lower than the limit value of the organic matter content in waste (30\% DM), which allows for biological treatment [16]. 
The organic carbon content in biofractions ranged from 15.8 to $29.3 \%$ DM. The average organic carbon content was $22.1 \pm 4.0 \%$ DM. The volatility index was $18 \%$.

\section{CONCLUSIONS}

The stream of organic fraction released from municipal waste on a sieve with a mesh of $80 \mathrm{~mm}$, during the heating season, makes up about $50 \%$ of the mass of waste delivered to the installation. The composition of the OFMSW is very diverse. The results show that about $1 / 3$ of the OFMSW $(34.0 \pm 10.6 \%)$ mass is a fine fraction $(<20 \mathrm{~mm})$, mainly furnace waste. The organics share was on average $39.3 \pm 10.4 \%$. There was also a fraction of "paper" in the bulk of OFMSW, an average of $10.5 \pm 4.3 \%$. The shares of other components did not exceed 5\%. The large number of batteries in OFMSM was surprising, despite their widespread selective collection.

Using MBT plants to extract organic waste from the MSW, an $80 \mathrm{~mm}$ sieve for screening passed on average $83.9 \pm 5.7 \%$ of biodegradable waste, the entire amount of fine fractions and large amounts of raw materials, such as paper, plastics, glass, metals and others. Most of these ingredients are inert or unwanted in biostabilization processes, but are valuable raw materials that should be recycled.

The effect of a high content of fine fraction (ash) and inert components in OFMSW emitted from the MSW during the heating season is low hydration and low waste incineration losses, which may even determine its inability to biological processing.

\section{ADDITIONAL INFORMATION}

The results presented here are based, mostly, on a large scale study of 20 MBT installations in Poland [20].

The project was implemented on the Order of the General Directorate for Environmental Protection co-financed from the European Union funds under the Operational Program Technical Assistance 2007-2013.

\section{REFERENCES}

1. Fricke K., Santen H., Wallmann R.: Comparison of selected aerobic and anaerobic procedures for MSW treatment. Waste Management, 25 (2005) 799-810.

2. Bockreis A., Steinberg I.: Influence of mechanical-biological waste pretreatment methods on the gas formation in landfills. Waste Management, 25 (2005) 337-343. 
3. Sormunen K., Einola J., Ettala M., Rintala J.: Leachate and gaseous emissions from initial phases of landfilling mechanically and mechanically biologically treated municipal solid waste residuals. Bioresource Technology 99, 7 (2008) 2399-2409.

4. Heyer K.U., Hupe K., Stegmann R.; Methane emissions from MBT landfills, Waste Management, 33, 9 (2013), 1853-1860.

5. Robinson H.D., Knox K., Bone B.D., Picken A.: Leachate quality from landfilled MBT waste. Waste Management, 25 (2005) 383-391.

6. De Gioannis G., Muntoni A.: Dynamic transformations of nitrogen during mechanical-biological pre-treatment of municipal solid waste. Waste Management, 27 (2007) 1479-1485.

7. Adhikari B.K., Barrington S., Martinez J., King S.: Effectiveness of three bulking agents for food waste composting, Waste Management, 29 (2009) 197-203.

8. Zhou H., Meng Y.Q., Long A.H., Li Q.H., and Zhang Y.G.: An overview of characteristics of municipal solid waste fuel in China: physical, chemical composition and heating value. Renew. Sustain. Energy Rev., 46 (2014) 107-122.

9. Jędrczak A.: Stan i prognoza rozwoju instalacji MBP $w$ Polsce. Stan i prognoza rozwoju instalacji MBP w Polsce. VI Konferencja MechanicznoBiologiczne Przetwarzanie Odpadów, 7-9 maja 2013 r., Elbląg. Wyd. Abrys. Perfekt Druk, Poznań. s. 101-110. ISBN: 83-89018-09-8.

10. Steiner M.: Status and trends in MBT across Europe, and relevant features. ISWA Beacon Conference Perugia, 15/16 April 2010.

11. The Market for Mechanical Biological Waste Treatment in Europe. 2nd edition, May 2017. Ecoprog GmbH. Pozyskano z: https://www.ecoprog.com/index.htm (14.11.2018)

12. Sprawozdania $\mathrm{z}$ realizacji Wojewódzkich Planów Gospodarki Odpadami w latach 2014-2016. Pozyskano z internet.

13. Epstein E., The science of composting, Technomic Publishing Com., Inc., Lancaster (USA) 1997.

14. Agnew J.M., Leonard J.J.: Physical properties of compost - a review. Compost Science and Utilization, 11 (2003) 138-264.

15. Jędrczak A.: Biologiczne przetwarzanie odpadów, PWN, Warszawa, 2007.

16. Bidlingmaier W.: Steurengsmöglichkeiten für biologische Verfahren über das Inputmaterial. 6. Münsteraner Abfallwirtschaftstage, Fachhochschule Münster, (1999) 206a - 206n.

17. Petric I., Helić A., Avdhodžić Avdić E.: Evolution of process parameters and determination of kinetics for co-composting of organic fraction of 
municipal solid waste with poultry manure. Bioresource Technology, 117 (2012) 107-116.

18. Jędrczak A.: Odzysk papieru, metali, tworzyw sztucznych $i$ szkła winstalacjach $M B P . \quad \mathrm{W}$ : Zarządzanie gospodarką odpadami. Technologiczno-organizacyjne aspekty gospodarowania odpadami. red. M. Górski, T. 1, Wydawca PZITS Poznań, Zakład Poligraficzny MośŁuczak sp.j., Poznań, 2013: 105-116.

19. Tuomela M., Vikman M., Hatakka A., Itävaara M.: Biodegradation of lignin in a compost environment: a review. Bioresource Technology 72 (2000) $169 \pm 183$.

20. Jędrczak, A., den Boer, E.: Final report of the 3rd stage of the study to carry out waste tests in 20 plants for mechanical and biological waste treatment, Zielona Góra 2015.

\section{WŁASCIWOŚCI FRAKCJI ORGANICZNEJ KIEROWANEJ DO BIOSTABILIZACJI W INSTALACJACH MBP W OKRESIE ZIMOWYM}

\section{Streszczenie}

W literaturze fachowej brak jest informacji na temat składu sitowego i morfologicznego OFMSW $(<80 \mathrm{~mm})$ poddawanej biologicznemu przetwarzaniu $\mathrm{w}$ instalacjach MBT w sezonie grzewczym. Wiedza o jakości tej frakcji jest ważna, ponieważ wpływa istotnie na przebieg procesu biostabilizacji. W artykule przedstawiono skład morfologiczny, skład sitowy, wilgotność, straty prażenia i zawartość węgla organicznego frakcji $<80 \mathrm{~mm}$ wydzielonych z odpadów komunalnych dostarczanych do 21 instalacji MBT w Polsce, w okresie zimowym. Wyniki pokazują, że około 1/3 masy OFMSW $(34,0 \pm 10,6 \%)$ stanowi frakcja drobna $(<20 \mathrm{~mm})$, głownie odpady paleniskowe. Udział organiki wynosił średnio $39,3 \pm 10,4 \%$. W dużej ilości w masie OFMSW występowała jeszcze frakcja „papier i tektura”, średnio - 10,5 $\pm 4,3 \%$. Udziały pozostałych składników nie przekraczały $5 \%$. Zaskakująca była duża liczba baterii w OFMSM, mimo powszechnego ich selektywnego zbierania. Efektem dużej zawartości frakcji drobnej (popiołów) i składników obojętnych w OFMSW w sezonie grzewczym jest niskie uwodnienie oraz niskie straty prażenia odpadów, które mogą nawet decydować o ich nieprzydatności do biologicznego przetwarzania.

Słowa kluczowe Odpady komunalne, Instalacje MBP, organiczna frakcja z odpadów komunalnych (biofrakcja), Systemy kompostowania, Frakcja organiczna, Odpady ulegające biodegradacji

Editor received the manuscript: 03.09.2018 